\title{
PEMBOBOTAN KATA BERDASARKAN KLASTER PADA OPTIMISASI COVERAGE, DIVERSITY DAN COHERENCE UNTUK PERINGKASAN MULTI DOKUMEN
}

\author{
Ryfial Azhar ${ }^{1}$, Muhammad Machmud ${ }^{2}$, Hanif Affandi Hartanto ${ }^{3}$ \\ Agus Zainal Arifin ${ }^{4}$, Diana Purwitasari ${ }^{5}$ \\ 1,2,3,4,5 Jurusan Teknik Informatika, Institut Teknologi Sepuluh Nopember \\ Kampus ITS Keputih, Sukolilo, Surabaya 60111, Jawa Timur, Indonesia \\ Email: ${ }^{1}$ ryfial.azhar14@mhs.if.its.ac.id, ${ }^{2}$ machmud14@mhs.if.its.ac.id, ${ }^{3}$ hanf_aff@apps.ipb.ac.id, \\ ${ }^{4}$ agusza@cs.its.ac.id, ${ }^{5}$ diana@if.its.ac.id
}

\begin{abstract}
Abstrak
Peringkasan yang baik dapat diperoleh dengan coverage, diversity dan coherence yang optimal. Namun, terkadang sub-sub topik yang terkandug dalam dokumen tidak terekstrak dengan baik, sehingga keterwakilan setiap sub-sub topik tersebut tidak ada dalam hasil peringkasan dokumen. Pada paper ini diusulkan metode baru pembobotan kata berdasarkan klaster pada optimisasi coverage, diversity dan coherence untuk peringkasan multidokumen. Metode optimasi yang digunakan ialah self-adaptive differential evolution (SaDE) dengan penambahan pembobotan kata berdasarkan hasil dari pembentukan cluster dengan metode Similarity Based Histogram Clustering (SHC). Metode SHC digunakan untuk mengklaster kalimat sehingga setiap sub-topik pada dokumen bisa terwakili dalam hasil peringkasan. Metode SaDE digunakan untuk mencari solusi hasil ringkasan yang memiliki tingkat coverage, diversity, dan coherence paling tinggi. Uji coba dilakukan pada 15 topik dataset Text Analysis Conference (TAC) 2008. Hasil uji coba menunjukkan bahwa metode yang diusulkan dapat menghasilkan ringkasan skor ROUGE-1 sebesar 0.6704, ROUGE-2 sebesar 0.2051, ROUGE-L sebesar 0.6271 dan ROUGE-SU sebesar 0.3951 .
\end{abstract}

Kata kunci :

peringkasan multi dokumen, similarity based histogram clustering, coverage, diversity, coherence

\section{Abstract}

Good summary can be obtained with optimizing coverage, diversity, and coherence. Nevertheless, sometime sub-topics wich is contained in the document is not extracted well, so that the representation of each subtopic is appear in docment summarizarion result. In this paper, we propose new of term weighting based on cluster in optimizing coverage, diversity, and coherence for multi-document summarization. Optimization method which is used is self-adaptive differential evolution $(S a D E)$ with additional term weighting based on clustering result with Similarity Based Histogram Clustering (SHC). SHC is used to cluster sentence so that every sub-topic in the document can be represented in summarization result. $\mathrm{SaDE}$ is used to search summarization result solution which has high coverage, diversity, and coherence level. Experiment is done on 15 topics in Text Analysis Conference (TAC) 2008 dataset. Experimental results show that this proposed method can produce summarization score ROUGE-1 0.6704, ROUGE-2 0.2051, ROUGE-L 0.6271 and ROUGE-SU 0.3951.

Keywords:

multy-document summarization, similarity based histogram clustering, coverage, diversity, coherence.

\section{Pendahuluan}

Ketersediaan dokumen secara online menyediakan informasi yang tidak terbatas. Namun, hal ini menyebabkan kesulitan mencari informasi yang relevan dan sesuai dengan kebutuhan kita. Banyak informasi yang memiliki tema yang sama berada di beberapa dokumen yang berbeda namun dan mengakibatkan redundansi informasi. Berdasarkan masalah di atas maka dibutuhkan sistem untuk meringkas dokumen - dokumen ini. 
Peringkasan dokumen secara otomatis ialah proses peringkasan dokumen yang mengekstrak informasiinformasi penting yang mewakili semua informasi yang ada pada dokumen asli secara relevan. Berdasarkan jumlah dokumen yang diproses, peringkasan dokumen dapat dikategorikan menjadi dua yaitu peringkasan dokumen tunggal dan multi-dokumen. Peringkasan dokumen tunggal ialah peringkasan yang hanya memproses satu dokumen untuk diringkas, sedangkan peringkasan multi-dokumen ialah peringkasan yang memproses lebih dari satu dokumen dengan topik yang sama untuk diringkas.

Hasil peringkasan yang baik ialah peringkasan mengandung tiga faktor yaitu cakupan pembahasan (coverage) yang luas, tingkat keberagaman (diversity), dan keterhubungan antarkalimat (coherence) yang tinggi (Alguliev, Aliguliyev, \& Isazade, 2013). Hasil ringkasan yang memiliki coverage yang tinggi merupakan ringkasan yang mengandung seluruh informasi dari dokumen asal. Ringkasan yang tinggi diversity-nya ialah ringkasan yang tidak mengandung informasi yang berulang (redundant). Keterkaitan masing - masing kalimat pada hasil ringkasan menandakan peringkasan yang memiliki coherence yang tinggi.

Penelitian mengenai peringkasan multi-dokumen yang memperhatikan coverage, diversity dan coherence telah dilakukan oleh penelitian sebelumnya (Umam, Putro, \& Pratamasunu, 2015), dimana dalam penelitian ini sistem optimasi dengan menggunakan algoritma Self-adaptive Differential Evolution (SaDE) diterapkan untuk meningkatkan ketiga faktor tersebut. Selanjutnya, Algoritma pengurutan kalimat yang menggunakan pendekatan topical closeness juga diintegrasikan ke dalam tiap iterasi algoritma SaDE untuk meningkatkan koherensi antarkalimat hasil ringkasan.

Penelitian lainnya mengenai peringkasan multidokumen dilakukan dengan metode clustering telah dilakukan dalam beberapa penelitian (Lukmana, Swanjaya, Kurniawardhani, Arifin, \& Purwitasari, 2014), (Pasnur, Santika, \& Syaifuddin, 2014), (Sarkar, 2009) (Suputra, Arifin, \& Yuniarti, 2013) pengklasteran kalimat dilakukan untuk meningkatkan coverage pada hasil peringkasan. Selain itu, pengklasteran kalimat bertujuan untuk mengentahui sub-sub topik yang terkandung dalam dokumen.

Proses untuk menghasilkan peringkasan yang baik dapat diperoleh tidak hanya dengan coverage, diversity dan coherence yang optimal. Namun, terkadang sub-sub topik yang terkandug dalam dokumen tidak terekstrak dengan baik, sehingga keterwakilan setiap sub-sub topik tersebut tidak ada dalam hasil peringkasan dokumen.

Pada paper ini dusulkan metode pembobotan kata berdasarkan klaster pada optimisasi coverage, diversity dan coherence untuk peringkasan multi-dokumen.

\section{METODE}

Pada bagian ini dijelaskan secara detil tahapan yang dilakukan sehingga menghasilkan ringkasan. Sesuai Gambar 1, secara garis besar ada tiga tahapan utama yang digunakan dalam penelitian ini, yakni term preparation, sentences clustering, dan proses pembentukan ringkasan dengan optimisasi. Tahap term preparation berkaitan dengan tahap ekstraksi kalimat dan kata dari dokumen sampai dengan pembentukan document-term vector dan pembobotannya. Sentences clustering berperan dalam mengelompokkan kalimat dari semua dokumen ke dalam klaster-klaster sesuai dengan kemiripan sub topik masingmasing kalimat. Proses optimisasi dengan algoritma SaDE bertujuan untuk menghasilkan ringkasan berdasarkan hasil dari pengelompokkan kalimat pada proses klasterisasi. Hasil akhir dari proses ini ditentukan melalui nilai fitness tertinggi pada coverage, diversity dan coherence hasil peringkasan dengan pembobotan kata berdasarkan klasterklaster yang telah terbentuk.

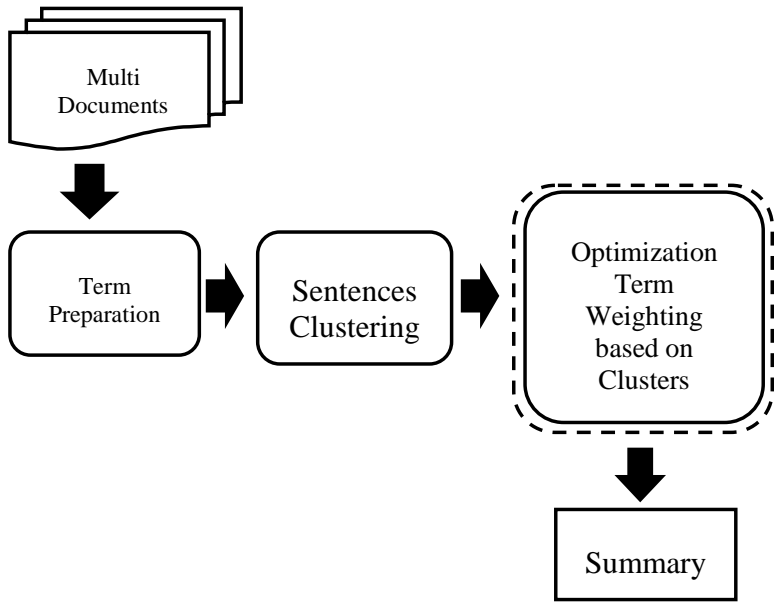

Gambar 1. Flowchart Metode usulan

\section{II.1 Term Preparation}

Term Preparation adalah tahapan untuk menyiapkan data yang digunakan pada proses utama. Tahapan ini bertujuan untuk menyiapkan data yang digunakan pada tahapan selanjutnya. Tahap term preparation ini terdiri dari proses pengambilan kalimat

Ryfial Azhar, Muhammad Machmud, Hanif Affandi Hartanto 
dari dokumen asal, proses ekstraksi term, stopword removal, stemming, dan pembobotan. Pada tahapan ini dihasilkan matriks dokumen-term, dan matriks dokumensentence dan bobot masing-masing.

\section{II.2 Clustering}

Proses clustering bertujuan untuk mengelompokkan kalimat-kalimat yang memiliki tingkat kemiripan tinggi ke dalam cluster-cluster tertentu. Pada tahap ini digunakan metode Similarity Based Histogram Ratio Clustering (SHC). Metode ini digunakan karena pendekatan dalam metode ini adalah cluster similarity histogram yang menjamin tiap cluster agar tetap coherent. Untuk menghitung tingkat kemiripan kalimat pada proses SHC ini menggunakan penelitian sebelumnya (Song \& Park, 2004) yaitu dengan pendekatan kemiripan semantik dengan metode Latent Semantic Indexing (LSI). Metode LSI mampu mengidentifikasi hubungan semantik antar term berdasarkan pola dan hubungan antara istilah dan konsep-konsep yang terkandung dalam koleksi teks (Wahib, Pasnur, Santika, \& Arifin, 2015).

Untuk menentukan kemiripan semantik dengan LSI dibutuhkan proses Singular Value Decomposition (SVD) terhadap matriks $\mathrm{X}$ yang memetakan term dan kalimat. Matriks X akan didekomposisi menjadi tiga buah matriks $\mathrm{U}, \sum$, dan V, sesuai dengan Persamaan 1.

$X=U \cdot \sum \cdot V^{T}$

Dengan U dan V merupakan matriks singular kiri dan kanan, sedangankan matriks $\sum$ merupakan matriks diagonal yang menunjukkan nilai singular.

Pengukuran nilai similarity yang digunakan adalah cosine similarity, yaitu perhitungan tingkat kemiripan berdasar pada besar sudut kosinus antara dua vektor sesuai Persamaan 2 :

$\operatorname{sim}\left(A_{v} B\right)=\cos (\theta)=\frac{A \cdot B}{\|A\|\|B\|}$

Dengan $\theta$ adalah sudut antara vektor $A$ dan vektor $B$.

Proses clustering kalimat adalah bagian yang penting dalam sistem peringkasan otomatis karena setiap topik dalam set dokumen harus diidentifikasi secara tepat untuk menemukan kemiripan dalam semua dokumen sehingga menjamin coverage yang baik (Sarkar, 2009). Jika kalimat-kalimat dikelompokkan ke dalam sejumlah cluster yang telah ditentukan, cluster mungkin tidak koheren karena beberapa kalimat bisa saja terpaksa menjadi salah satu anggota cluster meskipun seharusnya tidak. Cluster-cluster tidak koheren mungkin mengandung unit-unit teks yang terduplikasi pada cluster yang berbeda dan menyebabkan pemilihan kalimat menjadi redundan untuk ringkasan. Sebaliknya, jika cluster sangat ketat, sebagian besar cluster menjadi singletons. Dengan demikian, harus dipilih metode clustering yang menjamin koherensi cluster. Pada paper ini digunakan algoritma (Similarity Based Histogram Ratio) SHC yang diadopsi dari (Hammouda \& Kamel, 2003). SHC dipilih karena SHC menggunakan pendekatan cluster similarity histogram yang berguna untuk menjaga agar cakupan cluster.

Setiap cluster yang terbentuk harus memiliki koherensi yang baik pula. Hal tersebut untuk mencegah adanya kalimat-kalimat yang menginformasikan hal yang sama pada saat pemilihan kalimat penyusun ringkasan. Kualitas dari suatu similarity histogram yang merepresentasikan koherensi cluster ditentukan dengan menghitung rasio similarity yang berada diatas threshold dengan total jumlah similarity yang ada. Rasio dari histogram yang tinggi mencerminkan koherensi yang tinggi pula (Sarkar, 2009).

Misalkan pada suatu cluster terdapat $k$ buah kalimat, maka banyaknya similarity kalimat yang ada pada cluster tersebut sebanyak $k(k+1) / 2 . \operatorname{Sim}=\left\{\operatorname{sim}_{1}\right.$, $\left.\operatorname{sim}_{2}, \operatorname{sim}_{3}, \ldots, \operatorname{sim}_{\mathrm{p}}\right\}$ adalah kumpulan dari pasangan similarity antar kalimat, dengan nilai $p=k(k+1) / 2$. Similarity histogram dari cluster dinotasikan dengan $H=\left\{h_{1}, h_{2}, h_{3}, \ldots, h_{n b}\right\}$. Jumlah dari bin yang ada pada suatu histogram dinotasikan dengan nb sedangkan jumlah similarity kalimat yang ada pada bin ke-i dinotasikan dengan $h_{i}$. Fungsi untuk menghitung nilai $h_{i}$ ditunjukkan pada Persamaan 3.

$h_{i}=\operatorname{count}(\operatorname{sim})$

Untuk $\operatorname{sim}_{l i} \leq \operatorname{sim}_{j} \leq \operatorname{sim}_{u i}$, dengan $\operatorname{sim}_{l i}$ ialah batas minimum similarity pada bin ke-i sedangkan $\operatorname{sim}_{u i}$ ialah batas maksimum similarity pada bin ke-i.

Histogram ratio (HR) dari suatu cluster dapat dihitung dengan Persamaan 4.

$H R=\frac{\sum_{i=\pi^{n}}^{n_{b}} h_{i}}{\sum_{j=1}^{n} h_{j} h_{j}}$ 
melakukan simulasi penambahan kalimat baru pada

$T=\left\lfloor S_{T} * n_{b}\right\rfloor$

ST adalah similarity threshold. Persamaan 5 menunjukkan jumlah bin yang sesuai dengan similarity threshold yang dinotasikan dengan $\mathrm{T}$.

Penambahan anggota baru yang buruk pada suatu cluster pada setiap tahap akan berpengaruh terhadap kualitas cluster, dalam hal ini akan menurunkan nilai HR cluster tersebut. Untuk mengantisipasi hal tersebut maka harus ditetapkan HRmin, yakni histogram ratio minimum yang digunakan sebagai batas minimum pada penambahan anggota cluster baru. Detil algoritma SHC diperlihatkan pada pseudocode pada Gambar 2.

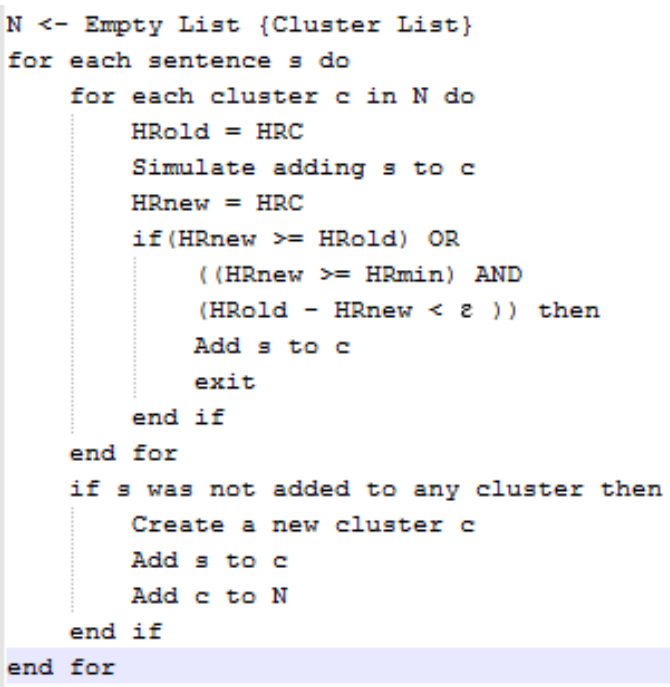

Gambar 2. Pseudocode Clustering Kalimat

Metode SHC berjalan secara bertahap sesuai Gambar 2 HRold adalah nilai histogram ratio pada suatu cluster sebelum penambahan kalimat baru kedalam cluster tersebut, sedangkan HRnew adalah histogram ratio yang diperoleh setelah sebuah kalimat dijadikan anggota dari suatu cluster yang diujikan. HRmin adalah nilai minimum dari histogram ratio pada cluster tertentu. Parameter $\varepsilon$ (epsilon) digunakan sebagai threshold selisih antara HRold dengan HRnew. SHC akan menguji setiap kalimat dimana cluster silmilarity histogram dari setiap cluster dihitung sebelum dan sesudah suatu cluster.

Pada saat membentuk cluster baru nilai histogram ratio disimpan pada HRC yang dihitung menggunakan Persamaan 3. Pada proses pembentukan cluster, HRold dan HRnew dibandingkan. Jika nilai HRnew lebih atau sama dengan nilai HRold, maka kalimat tersebut ditambahkan ke dalam cluster uji, atau jika nilai HRnew lebih rendah dari nilai HRold namun nilai HRnew masih berada diatas HRmin dan selisih antara HRold dengan HRnew tidak lebih dari $\varepsilon$ maka kalimat juga ditambahkan sedangkan selain itu kalimat tidak ditambahkan. Jika suatu kalimat tidak mendapatkan cluster setelah diuji dengan semua cluster, maka sebuah cluster baru dibentuk dan kalimat tersebut menjadi anggotanya.

\section{II.3 Optimisasi}

Proses optimisasi digunakan untuk membentuk ringkasan berdasarkan dokumen yang telah terkelompok. Optimisasi ini bertujuan untuk menentukan nilai coverage, diversity, dan coherence dengan tetap mengacu pada dokumen hasil clustering (dokumen cluster). Peringkasan yang baik bukan hanya memiliki coverage, diversity dan coherence yang optimal. Peringkasan yang baik juga harus mampu mewakili sub-sub topik yang terdapat dalam semua dokumen asal. Apabila sub-sub topik yang terkandung dalam masing-masing dokumen tidak terekstrak dengan baik, maka keterwakilan setiap sub-sub topik tersebut tidak terdapat dalam hasil peringkasan.

Untuk menjaga agar keterwakilan sub-sub topik pada semua dokumen asal terwakili, pada paper ini diusulkan metode pembobotan Term Frequency Inverse Class Frequency (TF-ICF). Pembobotan TFICF suatu term pada suatu dokumen cluster doc tergantung pada dua hal, jumlah term pada dokumen cluster doc, dan banyaknya dokumen cluster lain yang mengandung term tersebut. Semakin banyak jumlah term pada dokumen cluster doc maka semakin besar nilai bobot term tersebut, sebaliknya semakin sedikit jumlah term pada dokumen cluster doc maka semakin kecil nilai bobot term tersebut. Semakin banyak dokumen cluster yang mengandung term tersebut, maka semakin kecil nilai bobot term tersebut, Sebaliknya semakin sedikit dokumen cluster yang mengandung term tersebut, maka semakin besar nilai bobot term tersebut 
Notasi pembobotan TF-ICF yang digunakan pada paper ini sesuai dengan Persamaan 6 dan Persamaan 7. $W_{\text {term,doc }}$ menyatakan bobot dari term pada dokumen cluster asal doc, $t f_{\text {term,doc }}$ menyatakan banyaknya jumlah term pada dokumen cluster tertentu doc, icf term menyatakan Inverse Class Frequency term, yang menunjukkan pentingnya suatu term pada semua dokumen cluster asal dibandingkan dengan dokumen cluster tertentu doc.

$i c f_{\text {term }_{\text {d }} d o c}=\log \left(1+\frac{w}{N_{\text {term,dor }}}\right)$

$W_{\text {term, doc }}=t f_{\text {term,doc }} \times i c f_{\text {term,doe }}$

Pembobotan TF-ICF ini kemudian digunakan pada proses optimisasi coverage, diversity, dan coherence. Nilai coverage hasil peringkasan menunjukkan perbandingan cakupan isi ringkasan terhadap isi dalam dokumen cluster asal. Hal ini dapat dihitung dengan menghitung similarity antara center isi dalam dokumen cluster asal dengan center kandidat ringkasan, dimana center suatu dokumen adalah rata-rata bobot semua term dalam dokumen (Alguliev, Aliguliyev, \& Isazade, 2013). Nilai coverage juga turut mempertimbakan similarity antara dokumen cluster asal dengan tiap kalimat hasil peringkasan sesuai persamaan 8 .

$$
\begin{aligned}
& f_{\text {conerage }}= \\
& \sum_{i=1}^{n} \operatorname{sim}\left(O_{i}, O_{\text {sum }}\right) x \sum_{i=1}^{n} \sum_{j=1}^{m} \operatorname{sim}\left(O_{i}, \operatorname{sen}_{j}\right)
\end{aligned}
$$

$\operatorname{sim}\left(O_{i}, O_{\text {sum }}\right)$ menunjukkan similarity antara center dokumen cluster ke-i dengan center dari summary (hasil peringkasan). Perhitungan ini dilakukan untuk dokumen cluster ke-i sampai dengan $n$ dokumen cluster yang telah terbentuk. Sedangkan $\operatorname{sim}\left(O_{i}, \operatorname{sen}_{j}\right)$ menunjukkan similarity antara center dokumen cluster ke-i dengan sentences (kalimat) hasil peringkasan, mulai dari kalimat ke-j sampai dengan $m$ kalimat hasil ringkasan.

Nilai diversity ringkasan mencerminkan keragaman kalimat hasil peringkasan. Untuk menentukan diversity ringkasan dapat dilakukan dengan menghitung total similarity antara setiap kalimat dalam ringkasan, sesuai persamaan 9. Jika ringkasan memiliki total nilai kesamaan kalimat yang tinggi, maka ringkasan tersebut memiliki keanekaragaman yang rendah. Sebaliknya, jika ringkasan memiliki total nilai kesamaan kalimat yang rendah, maka ringkasan tersebut memiliki keragaman antara kalimat yang tinggi (Alguliev, Aliguliyev, \& Isazade, 2013).

$f_{\text {diversity }}=\sum_{j=1}^{m-1} \sum_{k=j+1}^{m} \operatorname{sim}\left(\operatorname{sen}_{j}, \operatorname{sen}_{k}\right)$

$\operatorname{sim}\left(\operatorname{sen}_{j}, \operatorname{sen}_{k}\right)$ menunjukkan similarity antara sentences (kalimat) hasil peringkasan, mulai dari kalimat ke-j sampai dengan $m$ kalimat hasil ringkasan. Proses ini dilakukan pada semua pasangan kalimat untuk mengetahui total kemiripan antar kalimat hasil peringkasan.

Nilai coherence mencerminkan tingkat coherences dalam kalimat dalam hasil ringkasan. Nilai coherence menunjukkan bahwa konektivitas antar kalimat dalam ringkasan yang cukup baik. Dengan tingkat coherences yang baik akan memudahkan pembaca untuk memahami informasi dalam ringkasan. Salah satu indikasi tingkat coherences yang baik adalah jika kalimat yang berdekatan membahas konten atau topik yang serupa, atau dengan kata lain memiliki simirality yang tinggi sesuai persamaan 10 .

$$
\begin{aligned}
f_{\text {coherences }}=\sum_{j=1}^{m-1} \operatorname{sim}\left(\operatorname{sen}_{m}, \operatorname{sen}_{m+1}\right) & \ldots[10] \\
\operatorname{sim}\left(\operatorname{sen}_{m}, \operatorname{sen}_{m+1}\right) & \text { menunjukkan }
\end{aligned}
$$
antara sentences (kalimat) hasil peringkasan, mulai dari kalimat ke-j sampai dengan $m$ kalimat hasil ringkasan. Proses ini dilakukan pada kalimat yang berurutan untuk mengetahui total kemiripan antar kalimat hasil peringkasan.

Metode optimasi yang digunakan ialah selfadaptive differential evolution (SaDE). Alur proses optimasi untuk peringkasan muti dokumen terdiri dari : inisialisasi populasi, binerisasi populasi, pengurutan, penghitungan nilai fitnes, mutasi, crossover dan seleksi, binerisasi trial vektor, pengurutan, dan pemeriksaan stopping criterion yang ditetapkan (Umam, Putro, \& Pratamasunu, 2015).

Pada proses penghitungan nilai fitness dilakukan untuk setiap solusi peringkasan sesuai persamaan 11. Evaluasi dilakukan untuk setiap kalimat asli yang telah dikodekan ke bentuk biner. Berdasarkan tujuan pada paper ini, perhitungan nilai fitness dilakukan dengan mempertimbangkan tiga 
faktor kualitas ringkasan ini, yaitu coverage, diversity dan coherence. Solusi terbaik dan terburuk di tiap generasi dapat ditentukan dengan menghitung nilai fitness masing-masing.

$$
\text { fitness }=\frac{f_{\text {coverrage }}}{f_{\text {diversity }}} x f_{\text {coherences }}
$$

\section{III.UJI COBA DAN EVALUASI}

Pada penelitian ini, data testing yang digunakan yaitu dataset Text Analysis Conference (TAC) 2008 dari National Institute of Standards and Technology (NIST). Percobaan ini dilakukan dengan memilih 15 topik pada data testing, dimana setiap topik terdiri dari 10 dokumen. Kemudian data testing tersebut dilakukan peringkasan dengan menggunakan metode yang diusulkan. Gambar 3 adalah contoh dari dokumen TAC 2008.

Percobaan dilakukan dengan menggunakan Matlab R2013a dan berjalan di platform Microsoft Windows. pengujian metode usulan dengan cara membandingkan hasil summarization antara metode usulan dengan metode CoDiCo. Pada proses klusterisasi kalimat digunakan kombinasi parameter uji optimal yang telah digunakan pada penelitian (Pasnur, Santika, \& Syaifuddin, 2014), dengan menetapkan batas nilai minimum $\left(\mathrm{HR}_{\min }\right)$, batas selisih maksimum antara $\mathrm{HR}_{\text {old }}$ dengan $\mathrm{HR}_{\text {new }}(\varepsilon)$, batas similarity bin pada perhitungan histogram ratio $\left(\mathrm{S}_{\mathrm{T}}\right)$ dengan nilai berturut-turut $0.1,0.2,1$. Selain itu, kedua algoritma yang digunakan yakni metode usulan dan CoDiCo akan diuji, untuk melihat seberapa berpengaruhnnya hasil klusterisasi kalimat terhadap metode usulan yang dibandingkan dengan metode CoDiCo. Skenario yang digunakan adalah melibatkan threshold $\mathrm{T}_{\text {sim }}$ pada nilai similarity kalimat untuk mengevaluasi dampak dari similarity antara kalimat peringkasan dengan solusi kalimat peringkasan yang optimal. Pada penelitian ini akan digunakan dua nilai threshold, yaitu 0,7 dan 0,9 .

Metode usulan dan metode CoDiCo menggunakan empat parameter yang telah ditentukan pada proses inisialisasi yaitu ukuran populasi $(\mathrm{P})$, generasi maksimum $\left(\mathrm{t}_{\max }\right)$, batas bawah $\left(\mathrm{u}_{\min }\right)$, dan batas atas $\left(\mathrm{u}_{\max }\right)$ dengan nilai $20,500,-5$, dan 5 . Nilai-nilai parameter tersebut ditetapkan berdasarkan pilihan heuristik. Setelah beberapa dokumen peringkasan diolah dengan menggunakan metode usulan, akan didapatkan hasil peringkasan sebanyak topik yang dipilih. Sehingga akan terbentuk 15 ringkasan untuk masing-masing 15 topik yang dipilih untuk setiap metode. Gambar 4 menunjukkan ilustrasi hasil pembentukan ringkasan multi dokumen.

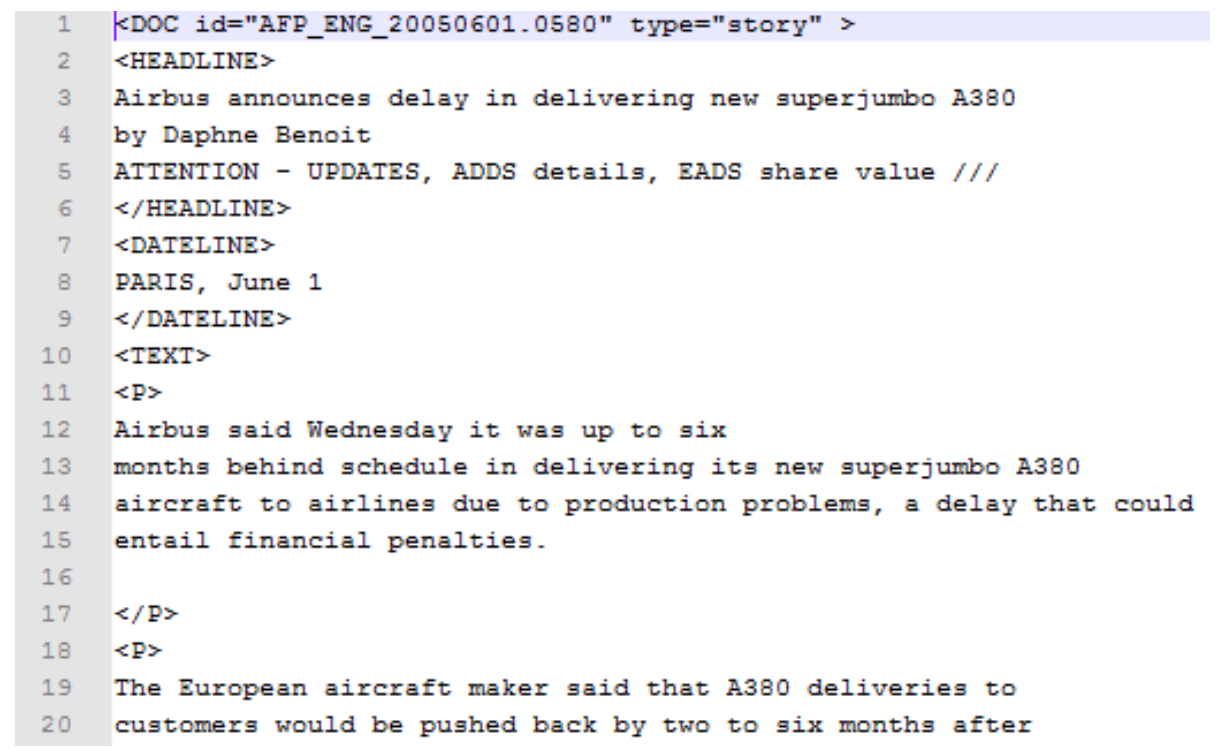

Gambar 3. Contoh Dokumen TAC 2008

Ryfial Azhar, Muhammad Machmud, Hanif Affandi Hartanto 


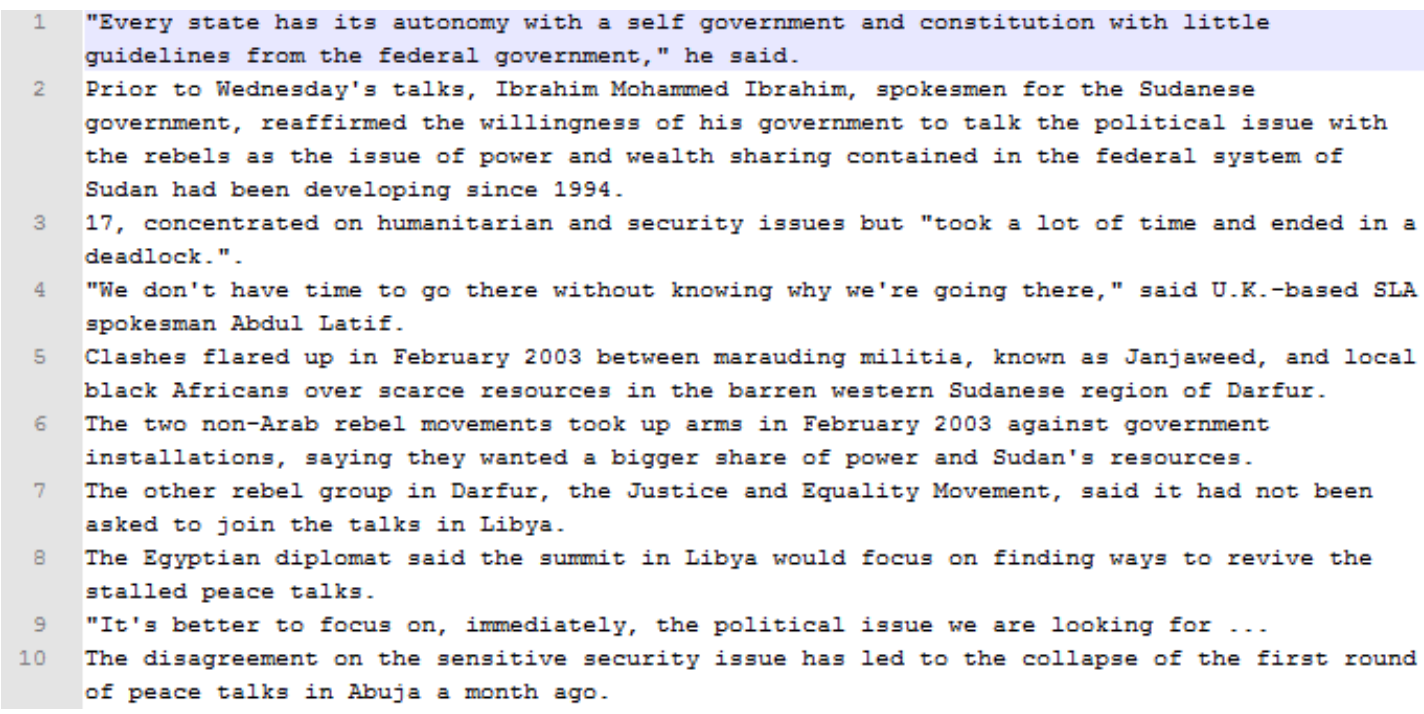

Gambar 4. Contoh Hasil Ringkasan

Hasil pengujian kemudian dievaluasi dengan menggunakan Recall-Oriented Understudy of Gisting (ROUGE) (Lin, 2004). Metode ROUGE yang digunakan untuk mengevaluasi percobaan ini adalah ROUGE-1, ROUGE-2, ROUGE-L dan ROUGE-SU. ROUGE-1 dan ROUGE-2 adalah varian dari ROUGE-N yang menganggap n-gram recall antara hasil ringkasan dari calon ringkasan dan referensi ringkasan untuk n yang diwakilkan dengan 1 dan 2 . ROUGE-L adalah metode ROUGE yang menganggap subsequence terpanjang antara calon ringkasan dan referensi ringkasan. Sedangkan ROUGE-SU menganggap nilai unigram pada calon ringkasan dan referensi ringkasan sebagai satu unit yang dihitung. Pada tahap evaluasi ini, mengacu pada metode CoDiCo di setiap nilai threshold yang digunakan.

\section{Hasil dan Pembahasan}

Hasil uji coba metode usulan dengan paratemer yang telah ditentukan sebelumnya dan threshold pada optimisasi sebesar 0.9, menunjukkan bahwa nilai ROUGE-1 tertinggi adalah 0.7893 untuk topik D0814CA. Untuk nilai ROUGE-2 dan ROUGE-SU tertinggi adalah 0.3822 dan 0.5677 untuk topik D0816CB. Sedangkan ROUGE-L tertinggi adalah 0.7521 untuk topik D0822DA. Hal tersebut dapat dilihat pada Tabel 1 .
Tabel 1. Hasil Metode Usulan pada Setiap Topik

\begin{tabular}{llllc}
\hline \hline TOPIK & $\begin{array}{l}\text { ROUGE- } \\
\mathbf{1}\end{array}$ & $\begin{array}{l}\text { ROUGE- } \\
\mathbf{2}\end{array}$ & $\begin{array}{l}\text { ROUGE- } \\
\text { L }\end{array}$ & $\begin{array}{l}\text { ROUGE- } \\
\text { SU }\end{array}$ \\
\hline \hline D0801AB & 0.7670 & 0.1638 & 0.7415 & 0.5171 \\
D0814CA & $\mathbf{0 . 7 8 9 3}$ & 0.2353 & 0.7438 & 0.5576 \\
D0814CB & 0.7030 & 0.1869 & 0.6287 & 0.4147 \\
D0816CB & 0.7773 & $\mathbf{0 . 3 8 2 2}$ & 0.6900 & $\mathbf{0 . 5 6 7 7}$ \\
D0821DB & 0.7409 & 0.1852 & 0.6891 & 0.3675 \\
D0822DA & 0.7607 & 0.3130 & $\mathbf{0 . 7 5 2 1}$ & 0.5196 \\
D0827EA & 0.5959 & 0.2199 & 0.5551 & 0.2329 \\
D0827EB & 0.2548 & 0.0275 & 0.2471 & 0.0510 \\
D0829FA & 0.7559 & 0.2080 & 0.7244 & 0.4530 \\
D0829FB & 0.5444 & 0.1429 & 0.5037 & 0.2198 \\
D0831FB & 0.7521 & 0.1609 & 0.7051 & 0.4969 \\
D0842GA & 0.7384 & 0.1717 & 0.6920 & 0.4987 \\
D0846HA & 0.3673 & 0.0856 & 0.3496 & 0.1109 \\
D0846HB & 0.6786 & 0.2727 & 0.6250 & 0.3854 \\
D0847HA & 0.7778 & 0.3024 & 0.7064 & 0.4829 \\
\hline \hline
\end{tabular}

Telah dilakukan percobaan untuk mengetahui apakan dengan penambahan pembobotan kalimat berdasarkan klaster pada optimasi coverage, diversity

Ryfial Azhar, Muhammad Machmud, Hanif Affandi Hartanto 
dan coherence untuk peringkasan multi-dokumen dapat meningkatkan kualitas hasil peringkasan dengan tetap mengacu pada metode sebelumnya yaitu CoDiCo (Umam, Putro, \& Pratamasunu, 2015). Berdasarkan percobaan yang telah dilakukan pada Tabel 2.

Tabel 2. Perbandingan Nilai Rouge Setiap Metode

\begin{tabular}{lcccc}
\hline \hline METODE & $\begin{array}{c}\text { ROUGE- } \\
\mathbf{1}\end{array}$ & $\begin{array}{r}\text { ROUGE- } \\
\mathbf{2}\end{array}$ & $\begin{array}{c}\text { ROUGE- } \\
\text { L }\end{array}$ & $\begin{array}{c}\text { ROUGE } \\
\text {-SU }\end{array}$ \\
\hline \hline $\begin{array}{l}\text { CODICO } \\
\text { th=0.7) }\end{array}$ & 0.6063 & 0.1795 & 0.5709 & 0.2972 \\
$\begin{array}{l}\text { CODICO } \\
\text { th=0.9) }\end{array}$ & 0.5506 & 0.1599 & 0.5167 & 0.2630 \\
$\begin{array}{l}\text { METODE } \\
\text { USULAN } \\
\text { (th=0.7) }\end{array}$ & 0.2252 & 0.0276 & 0.2181 & 0.0691 \\
$\begin{array}{l}\text { METODE } \\
\text { USULAN } \\
\text { (th }=0.9)\end{array}$ & 0.6704 & 0.2051 & 0.6271 & 0.3951 \\
\hline \hline
\end{tabular}

Metode usulan dengan menggunakan threshold 0.9 menujukan hasil evaluasi menggunakan ROUGE1, ROUGE-2, ROUGE-L dan ROUGE-SU yang lebih tinggi dibandingkan metode sebelumnya yaitu sebesar 0.6704, 0.2051, 0.6271 dan 0.3951. Pada threshold 0.8 , metode usulan memperoleh hasil yang kurang memuaskan dan jauh dibandingkan hasil dari metode sebelumnya. Hal ini menujukkan bahwa dengan menggunakan pembobotan berdasarkan kluster pada peringkasan mengakibatkan ketidak stabilan hasil yang diperoleh jika menggunakan threshold yang tidak sesuai. Namun, dengan threshold yang tepat, metode ini dapat meningkatkan akurasi dengan sangat baik.

Dengan menambahkan pembobotan kalimat berdasarkan klaster, hal ini mengakibatkan sub-sub topik dalam dokumen terekstrak dengan baik sehingga keterwakilan sub-sub topik tersebut berada dalam hasil peringkasan dokumen. Hal ini dapat mengakibatkan hasil peringkasan yang lebih baik dari pada metode sebelumnya karena tidak ada redundansi kalimat karena tiap kalimat mewakili tiap sub topik yang ada.

Dengan metode pengklasteran Similarity Based Histogram Ratio Clustering (SHC), pada awal proses akan menjamin keterwakilan sub-sub topik dalam dokumen yang akan diringkas hadir dalam peringkasan dan akan mengurangi kalimat yang redundant. Hal ini berkaitan dengan beberapa penelitian sebelumnya yang menggunakan pengklasteran SHC (Lukmana, Swanjaya, Kurniawardhani, Arifin, \& Purwitasari, 2014), (Sarkar, 2009), (Pasnur, Santika, \& Syaifuddin, 2014).

\section{KESIMPULAN}

Teknik clustering dengan Similarity Based Histogram Ratio Clustering (SHC) dapat diimplementasikan sebagai salah tahapan persiapan untuk peringkasan multi dokumen. Implementasi tersebut dilakukan dengan memanfaatkan prinsip kerja LSI dan SHC untuk pembentukan cluster kalimat secara semantik. Selanjutnya hasil clustering digunakan sebagai dasar pada proses pembentukan ringkasan dokumen dengan optimisasi menggunakan self-adaptive differential evolution (SaDE) dan pembobotan dengan TF-ICF.

Hasil pengujian metode yang diusulkan mampu mencapai nilai ROUGE-1 sebesar 0.6704, ROUGE-2 sebesar 0.2051, ROUGE-L sebesar 0.6271 dan $R O U G E-S U$ sebesar 0.3951. Nilai ROUGE-1 metode yang diusulkan lebih tinggi $21 \%$ dari metode CODICO. Nilai ROUGE-2 metode yang diusulkan lebih tinggi $28 \%$ dari metode CODICO. Nilai ROUGE-L metode yang diusulkan lebih tinggi $21 \%$ dari metode CODICO. Sedangkan nilai ROUGE-SU metode yang diusulkan lebih tinggi $50 \%$ dari metode CODICO. Dengan demikian metode yang diusulkan layak untuk diimplementasikan pada peringkasan multi dokumen.

\section{REFERENSI}

Alguliev, R. M., Aliguliyev, R. M., \& Isazade, N. R. 2013. Multiple documents summarization based on evolutionary optimization algorithm. Expert Systems with Applic tions, 40, 1675-1689.

Hammouda, K., \& Kamel, M. 2003. Incremental Document Clustering Using Cluster Similarity Histograms. IEEE/WIC International Conference on Web Intelligence (WI'03). IEEE.

Lin, C.-Y. 2004. ROUGE: A Package for Automatic Evaluation Summaries. in Proceedings of

Ryfial Azhar, Muhammad Machmud, Hanif Affandi Hartanto 
the workshop on text summarization branches out, (hal. 74-81). Spain.

Lukmana, I., Swanjaya, D., Kurniawardhani, A., Arifin, A. Z., \& Purwitasari, D. 2014. MultiDocument Summarization Based On Sentence Clustering Improved Using Topic Words. Jurnal Ilmiah Teknologi Informasi.

Pasnur, Santika, P., \& Syaifuddin, G. 2014. Semantic Clustering Dan Pemilihan Kalimat Representatif Untuk Peringkasan Multi Dokumen. Jurnal Teknologi Informasi dan Ilmu Komputer, 91-97.

Sarkar, K. 2009. Sentence Clustering-based Summarization of Multiple Text Documents. International Journal of Computing Science and Communication Technologies.

Song, W., \& Park, S. C. 2004. Genetic Algorithm for Text Clustering Based on Latent Semantic
Indexing. Computers and Mathematics with Applications, 1901-190.

Suputra, I. H., Arifin, A., \& Yuniarti, A. 2013. Pendekatan Positional Text Graph Untuk Pemilihan Kalimat Representatif Cluster Pada Peringkasan Multi-Dokumen. Jurnal Ilmiah Ilmu Komputer.

Umam, K., Putro, F. W., \& Pratamasunu, G. Q. 2015. Coverage, Diversity, and Coherence Optimization For Multi-Document Summarization. Jurnal Ilmu Komputer dan Informasi.

Wahib, A., Pasnur, Santika, P., \& Arifin, A. 2015. Perangkingan Dokumen Berbahasa Arab Menggunakan Latent Semantic Indexing. Jurnal Buana Informatika 